\section{Diane Blair}

Diane Blair died on Monday, June 26, 2000, at the age of 61 . She left family, thousands of students, and friends all the way from Arkansas to the White House. Her loss is felt keenly by a large, admiring number of political scientists to whom she was always the best of colleagues and the most delightful of friends.

Her New York Times obituary notes some of the significant benchmarks in her life: Diane was born in Washington. She graduated Phi Beta Kappa from Cornell University in 1959 and received an M.A. in political science from the University of Arkansas in 1967. In between, she worked as an analyst for the President's Committee on Government Contracts, a researcher for the Senate Special Committee on Unemployment, and legislative secretary to Senator Stuart Symington (D-MO). After moving to Arkansas, she served Governors Dale Bumpers and David Pryor in various ways.

Political scientists know the Diane who taught and practiced politics in Arkansas for 30 years, almost all of them at the University of Arkansas in Fayetteville. She was a mainstay of the Democratic Party. She loved politics and she loved Southern politics most of all.

But those of us who knew and loved her knew that she had a very special affection and concern for women and politics, and for scholarship about them. More than 20 years ago, when gender politics scholars were thin on the ground and lightly regarded, Diane brought her inimitably stylish, incisive, energetic mind to bear on advancing women's fortunes at the polls and in the scholarly literature. As Diane D. Kincaid, in the same year that saw her marry Jim Blair, she published Silent Hattie Speaks: The Personal Journal of Senator Hattie Caraway (Greenwood Publishing, 1979). Diane was enduringly fond of Senator Carraway, the first woman to be elected to the U.S. Senate. (Senator
Caraway of Arkansas was appointed to replace her late husband, then won election to fill his unexpired term, and subsequently won election to two more terms.) In that year, as we've said, she also married Jim, with Bill Clinton officiating at the ceremony, and Hilary Rodham Clinton standing as "best person." The Blairs then raised their blended family of two sons and three daughters, while Diane went on teaching, writing, and working for women in American politics.

Most know of the intellectual excitement of Diane's last decade-her status as a senior campaign advisor in 1992, her work as the official campaign historian of the 1992 ClintonGore election campaign, her appointment to the Board of Governors of the Corporation for Public Broadcasting, all while teaching and writing and giving to her beloved Arkansas. All of this, as astonishing as it sounds, seemed merely routine for Diane. In all the years we knew her, she showed us how to fill each moment of life with productive action, quick intelligence, and even quicker laughter. She was a zestful and generous colleague who taught all how to savor the essence of life.

We would encourage all of Diane's friends to make a donation to the fund for APSA's Victoria Schuck Award for the Best Book in the field of gender politics or to the fund for the Marguerite Ross Barnet Award, in Diane Blair's memory. We miss her much, but celebrate her wonderful life.

Sue Tolleson-Rinehart, University of North Carolina, Chapel Hill Virginia Sapiro, University of Wisconsin, Madison

\section{Edward M. Goldberg}

Edward M. Goldberg, who served in a variety of administrative and academic posts at California State University, Los Angeles, died on August 21, 2000, at the age of 69, from lung cancer.
Ed was brought up in Brooklyn, New York, and received his B.A. in 1953 from Brooklyn College, an institution he often remembered with fondness. He received an M.A. from the University of New Mexico in 1956 and his Ph.D. from the University of Pennsylvania in 1965 . He taught at the University of New Mexico, San Diego State University, the University of Southern California, and CSU-Los Angeles, joining the faculty there in 1961 and rising through the ranks from assistant to full professor. He was drafted to serve in the Army during the Korean war.

Ed had a distinguished career on campus, where, at one point, he knew virtually every staff member and a good portion of the faculty as a result of his serving in several administrative and academic positions. He chaired the department of political science from 1972 to 1977 . He was assistant dean of the School of Letters and Sciences from 1968 to 1970 and associate dean of that school and its successor, the School of Natural and Social Sciences from 1981 through 1989. He was a member of the Executive Committee of the Academic Senate for over a decade and served as both vice chair and chair of that body. He was the senate member on the president's cabinet and a member of virtually every senate and administrative committee on campus over the course of his career. He chaired many of these.

He had received the campus Outstanding Professor Award, the campus' highest honor, in recognition of his teaching, research, and service, in 1985. His was one of only four Outstanding Professor Awards received by the more than 30 faculty who served in the department of political science since the 1960s.

Ed taught American constitutional law, judicial process, and comparative judicial studies over the course of his career. His senior seminar on legal research was renowned for preparing students to succeed in law school. Students who had to take 
the class at first feared it because the workload was demanding and the standards were unbending. Yet, many students later praised the seminar as their most valuable undergraduate course.

Ed took particular pride in mentoring minority and female students, guiding many to professional and Ph.D. programs. Many of his students went on to successful careers in law and political science across the nation.

He wrote seven monographs, four book chapters, and a dozen articles in the areas of judicial process and comparative legal studies. He headed a research project on privacy and computers in the 1960s, which resulted in a book on the subject published in 1975. His work appeared in such journals as the Journal of Public Law, Southern California Law Review, American Bar Association Journal, Canadian Journal of Women and the Law, Urban Affairs Quarterly, and National Civic Review.

He chaired a panel, presented a paper, or served as a discussant at more than 50 professional meetings, including those of the Research Committee on Comparative Judicial Studies of the International Political Science Association and the Western Political Science Association. He was the president, the vice president, and a member of the Executive Committee of the Western Political Science Association; his years as an executive in the WPSA are still remembered for their efficiency. $\mathrm{He}$ was an associate editor of the Western Political Quarterly in the 1980s. He was a member of the Research Committee on Comparative Judicial Studies of the International Political Science Association and was elected president and vice president of the Southern California Political Science Association He delivered invited lectures at the University of Notre Dame Law School, North Dakota State University, and Kearney State College (NE).

He received three National Endowment for the Arts Summer Seminar Fellowships, which enabled him to spend the summer studying subjects that were new to him. The one he particularly loved was a seminar on Shakespeare, during which he analyzed the politics of Shake- speare's plays and characters. He served as a consultant or principal investigator on projects involving topics as varied as privacy and computers (U.S. Department of Housing and Urban Development) and reapportionment (California State Assembly and Senate, UC-Davis). He also served as a research associate at the Fels Institute of Local and State Government at the University of Pennsylvania and the Taxpayers' Association of New Mexico.

This catalog of positions and activities makes too little of the fact that in a world of academic diplomats and soft-spoken people, Ed Goldberg was a lion-in his views, his values, and even the volume of his voice. He spoke with gusto, representing traditional academic values with verve. He strongly believed in Cal State-LA's mission. After all, Brooklyn College, where Ed got his B.A., is much like Cal State-Los Angeles. Both are urban institutions serving mostly students who will be the first in their families to graduate from college. He believed in the faculty of this institution and in faculty governance, as his attempts to implement joint consultation and decision making while he was chair of the academic senate proved. He will be missed in his department, in the academic senate, and in the university as a whole.

$\mathrm{He}$ is survived by his wife, Dorothy, and two children, David and Natalie.

\section{California State University, Los Angeles Donald W. Bray, Califormia State University, Los Angeles Edward S. Malecki, California State University, Los Angeles Benjamin W. Smith, California State University, Los Angeles Kenneth A. Wagner, California State University, Los Angeles}

\section{James P. Lester}

James P. Lester, professor of political science at Colorado State University, died May 17, 2000, in Berlin, Germany, at the age of 55, while completing his tenure as the J. William Fulbright Distinguished Chair in political science at the Institut fur Sozialwissenschaften at HumboldtUniversitat zu Berlin. Jim was born in Oklahoma, and was awarded his
B.A. and M.A. from the University of Oklahoma. He received his Ph.D. from George Washington University in 1980 , specializing initially in international relations. His academic journey led him to begin a study of environmental politics and public policy in the early 1980 s, and these subjects became the hallmarks of his subsequent career.

In addition to his tenure at Colorado State University, which began in 1983 and resulted in promotion to the rank of professor in 1989, Jim taught at Texas A\&M University and had either taught, delivered lectures, or been a visiting researcher in such locations as Mansfield College of Oxford University, the Technical University of Budapest, the Academie Internationale de l'Environnment at the Unversite of Geneva, the University of Linkoping in Sweden, the Martin School of Public Administration at the University of Kentucky, and the Council of State Government's Center for Environment and Natural Resources.

Jim played a highly visible role in the public policy field. He had served as chair of APSA's public policy section's nominations committee and as a member of the Executive Committee for the APSA Organized Section on Science,

Technology and Environmental Politics. Jim was also active in the Policy Studies Organization, serving as chair of the Theodore Lowi Awards Committee and the Science and Technology Advisory Group. He was a member of the Joint U.S.-Japan Study on Energy and the Environment Advisory Group and, for several years, organized environmental policy panels for the Western Political Science Association's annual meeting.

During his career Jim authored or coauthored a wide variety of articles that appeared in World Affairs, Western Political Quarterly, Policy Studies Review, Polity, and State and Local Government Review, to list but a few. In addition, he contributed more than 25 chapters to edited collections covering such topics as intergovernmental relations, federalism, public policy, and environmental policy. He authored, coauthored, or served as editor for a variety of books during his career, including Public Policy: An Environmental Ap- 